\title{
PREPARATION OF ALUMINIUM HYDROXIDE WITH MECHANOCHEMICAL SYNTHESIS IN THE MIDDLE SCHOOL LABORATORY LESSON
}

\author{
SYNTEZA MECHANOCHEMICZNA WODOROTLENKU GLINU \\ W LABORATORIUM CHEMICZNYM W GIMNAZJUM/LICEUM
}

\begin{abstract}
Mechanochemical reactions proceed if solid reactants combine together by grinding, milling or kneading with no or minimal solvent. It is possible to observe changes: fizzing, foaming, colour changes, water release. This process is manually simple and there are several mechanochemical reactions which can be demonstrated during school laboratory lessons. For high school pupils there exist five possibilities of inorganic synthesis: mechanochemical synthesis, crystallisation, precipitation, filtration and decantation. The preparation of aluminium hydroxide in the school laboratory is described in this paper. Five mechanochemical reaction schemes were tested by pupils in their laboratories. The pupils conducted the experiments and filled in worksheets to accompany the practical. On the basis of their results, a suitable procedure for school use is suggested.
\end{abstract}

Keywords: mechanochemical synthesis, pupils’ laboratory skills, aluminium hydroxide

\section{Introduction and theoretical background}

Nowadays science teaching and learning are living down the rebirth. The impact is given on developing pupils's skills and habits in laboratory work. There are many different laboratory exercises, which are not very complicated. There exists a group of chemical reactions, which are based on mechanical force, they are safe and not very strenuous for high school pupils. They are called mechanochemical reactions and they are rarely offered in chemistry textbooks to teachers for chemistry lessons.

Mechanochemistry connects mechanical and chemical phenomena on a molecular scale and includes mechanical breakage and the chemical behaviour of mechanically stressed solids [1]. It is possible to synthesize chemical products by using only mechanical action. Mechanical energy changes into chemical form. The mechanisms of mechanochemical transformations are often complex and different from usual thermal or photochemical mechanisms $[2,3]$. The method of ball milling is a widely used process in which mechanical force is used to achieve chemical processing and transformations [4].

\footnotetext{
${ }^{1}$ Department of Didactics, Psychology and Pedagogy, Comenius University in Bratislava, Mlynská dolina, Ilkovičova 6, 84215 Bratislava, Slovakia

${ }^{2}$ Department of Inorganic Chemistry, Faculty of Natural Sciences, Comenius University in Bratislava, Mlynská dolina, Ilkovičova 6, 84215 Bratislava, Slovakia

*Corresponding author: halakova@fns.uniba.sk
} 
A mortar and pestle are very often used as well [5]. Mechanochemical reaction proceeds if solid reactants conduct together by grinding with no or minimal solvent $[6,7]$.

Nowadays mechanochemical techniques and processes are very well studied and the interest in it is widely spread in recent chemical industry (in nanotechnologies). Grinding, milling or kneading procedures are often used as alternatives to preparative strategies. Intensive grinding causes carrying of mechanical energy, the number of reactants' contacts rises. During the grinding of reactants it is possible to observe changes: fizzing, foaming, colour changes, water release [8].

Mechanochemical preparation of substances have several advantages: solvent is not needed; cheap and available chemicals (anhydrous chlorides, nitrates, sulphates) are used, time-saving procedures are common [8]. Mechanochemical syntheses avoid or considerably reduce the use of reaction solvents, they are practical, advantageous [7]. The increased solid-state reactivity generated by mechanical energy imparted to the reactants by grinding or milling can offer alternative synthetic routes, occasionally yielding products not obtainable via solution chemistry. Small volumes of solvents added during grinding can control the polymorphic form of the products [9]. On the other hand in many cases mechanochemical synthesis is actually faster and more convenient than the original solvent-based methods [6]. Many researchers see mechanochemical syntheses as environmentally friendly alternatives to solution-based chemistry $[6,9,10]$. They have application not only in the chemical industry, but also in pharmaceutics and medicine [10, 11] for making active pharmaceutical ingredients. They have an important impact on the development and direction of pharmaceutical and medicinal chemistry [11].

Disadvantages: This kind of synthesis has limited reproducibility [8]. Studying mechanisms of mechanochemical reactions could be very difficult [10] and many methods are used (in situ diffraction of high-energy synchrotron X-rays [11], ESCA [12]). The use of powder X-ray diffraction data is essential for structure determination [13]. The reaction profiles are directly monitored, as well as the formation of intermediates, interconversions of framework topologies [10], mechanochemical screening for molecular recognition is usually done [11].

Many experiments have been done in this way. Berry et al. [14] introduced useful upper-level undergraduate inorganic experiment for preparing catalyst for Suzuki-Miyaura coupling by grinding the two powders in the solid state concr. palladium(II) chloride with 1,5-bis(diphenylphosphino)pentane in combination with a reflux in an atmosphere of nitrogen. Rojac et al. [15] studied the mechanochemical reaction of the $\mathrm{K}_{0,5} \mathrm{Na}_{0,5} \mathrm{NbO}_{3}$ solid solution (KNN). Wixtrom et al. [9] described an undergraduate organic chemistry experiment, the reaction of tetrathafulvalene and chloranil involving liquid-assisted grinding. Cheung et al. [13] have prepared a three component molecular cocrystal material via a solvent-free route involving the mechanical grinding of pure phases of the individual components. Garay et al. [6] introduced the synthesis of mononuclear complex, coordination clusters, spacious coordination cages, and 1-, 2- and 3-dimesional coordination polymers. Klissurski and Uzunova [12] investigated the phase segregation of copper cobaltite to copper oxide and a cobaltite of higher cobalt content by a mechanochemical reaction. Li and Liang [16] described the oxidation kinetics and mechanism of ilmenite which had been milled in air, and also in an atmosphere of oxygen. Užarevič et al. [17] provided the first direct evidence of how a formally dry milling reaction is facilitated by water released from a hydrated reactant. Researchers revealed a change in 
reaction mechanism if the temperature was increased, and also a strong dependence of the reaction rate on temperature.

Mechanochemical procedures often help to accelerate reactions but in some cases can also open up different reactions that lead to new products [5]. Why not try simple laboratory exercises at schools in that way?

Laboratory work is for pupils an irreplaceable source of specific skills and habits: different aspects of their personality are developing, their working activity and sometimes self-activity and creativity are also developing. Chemical experiments help to enhance the pupils' interest in chemistry learning, can help to develop their intellectual and manual skills. In the laboratory environment they can learn how to prepare a solution with certain composition, or concentration, how to dilute or concentrate a solution, and how to mix solutions together.

\section{Synthesis of an inorganic substance}

According to the National Curriculum there are several laboratory operations with which pupils need to be familiar with. They should be aware of safe work rules, of laboratory tools and several basic laboratory operations such as work with a Bunsen burner, warming of substances in test-tubes, use of a measuring cylinder, pipetting, working with a two-pan balance, standard chemical tests. Pupils' experiments are simple: observing is the essence, their chemical background knowledge is much less important. Pupils can develop their skills in basic separating and purifying methods: filtration, distillation, crystallization/re-crystallization, precipitation, decantation.

Teachers' experiments demonstrate changes of states of matter caused by warming, dissolving substances in water, preparing a saturated solution, the procedure for the dehydration of crystalline substances, warming and burning substances, working with concentrated solutions, with a thermometer, graduated cylinder, Bunsen burner, and the technique used for titration.

For high school pupils there exists five possibilities of inorganic synthesis: mechanochemical synthesis, crystallisation, precipitation, filtration, decantation. There are several possibilities how to use the mechanochemical reactions in laboratory at high schools. Teachers have to respect several limitations which depend on pupils'skills, their possibilities of using or not using chemicals, safety of chemicals (non carcinogenic, non toxic etc.).

The following criteria were adopted: didactic aspects, laboratory safety, chemicals (non toxic, non carcinogenic, non mutagenous, not too expensive), adequately demanding of manipulative skills, visual effect, time (till 90 minutes synthesis), character of work and product (synthesis with adequate yield, less or without additives).

The syntheses were laboratory-proven, and they were modified as necessary and procedures were optimized.

\section{Mechanochemical synthesis: Preparation of aluminium hydroxide}

Five mechanochemical reaction schemes were tested (1)-(5). There are modifications of the reaction (1) [8]:

$$
\begin{gathered}
\mathrm{AlCl}_{3} \cdot 6 \mathrm{H}_{2} \mathrm{O}+3 \mathrm{NaHCO}_{3} \rightarrow \mathrm{Al}(\mathrm{OH})_{3}+3 \mathrm{NaCl}+3 \mathrm{CO}_{2}+6 \mathrm{H}_{2} \mathrm{O} \\
2 \mathrm{AlCl}_{3} \cdot 6 \mathrm{H}_{2} \mathrm{O}+3 \mathrm{Na}_{2} \mathrm{CO}_{3} \rightarrow 2 \mathrm{Al}(\mathrm{OH})_{3}+6 \mathrm{NaCl}+3 \mathrm{CO}_{2}+9 \mathrm{H}_{2} \mathrm{O}
\end{gathered}
$$




$$
\begin{gathered}
2 \mathrm{AlCl}_{3} \cdot 6 \mathrm{H}_{2} \mathrm{O}+3 \mathrm{Na}_{2} \mathrm{CO}_{3} \cdot 10 \mathrm{H}_{2} \mathrm{O} \rightarrow 2 \mathrm{Al}(\mathrm{OH})_{3}+6 \mathrm{NaCl}+3 \mathrm{CO}_{2}+39 \mathrm{H}_{2} \mathrm{O} \\
2 \mathrm{KAl}\left(\mathrm{SO}_{4}\right)_{2} \cdot 12 \mathrm{H}_{2} \mathrm{O}+6 \mathrm{NaHCO}_{3} \rightarrow 2 \mathrm{Al}(\mathrm{OH})_{3}+3 \mathrm{Na}_{2} \mathrm{SO}_{4}+\mathrm{K}_{2} \mathrm{SO}_{4}+6 \mathrm{CO}_{2}+12 \mathrm{H}_{2} \mathrm{O} \\
2 \mathrm{KAl}\left(\mathrm{SO}_{4}\right)_{2} \cdot 12 \mathrm{H}_{2} \mathrm{O}+3 \mathrm{KHCO}_{3} \rightarrow \mathrm{Al}(\mathrm{OH})_{3}+2 \mathrm{~K}_{2} \mathrm{SO}_{4}+3 \mathrm{CO}_{2}+12 \mathrm{H}_{2} \mathrm{O}
\end{gathered}
$$

Description and observation are in Tables 1 and 2.

Survey of mechanochemical synthesis $\mathrm{Al}(\mathrm{OH})_{3}$ from $\mathrm{AlCl}_{3} \cdot 6 \mathrm{H}_{2} \mathrm{O}$

\begin{tabular}{|c|c|c|c|}
\hline \multirow{2}{*}{ Reagent } & \multicolumn{2}{|c|}{$\mathbf{A l C l}_{\mathbf{3}} \cdot \mathbf{6} \mathbf{H}_{2} \mathbf{O}$} & $\mathbf{N a}_{2} \mathbf{C O}_{3}$ \\
\cline { 2 - 4 } Observation & $\begin{array}{c}\text { After 5 minutes grinding } \\
\text { mixture started foaming } \\
\text { and fizzing, by stirring } \\
\text { water lost, mixture was } \\
\text { homogenous and well } \\
\text { spread. }\end{array}$ & $\begin{array}{c}\text { Mixture was not homogenous as } \\
\text { in using } \mathbf{N a H C O}_{3} \text {, and fizzing } \\
\text { was observed during the stirring. }\end{array}$ & $\begin{array}{c}\text { No changes (such as } \\
\text { fizzing or foaming) } \\
\text { were observed (during } \\
\text { the mixing of the } \\
\text { reagents). }\end{array}$ \\
\hline Product & $\begin{array}{c}\text { A white gelatinous } \\
\text { precipitate was formed, } \\
\text { which settled well in } \\
\text { water. }\end{array}$ & $\begin{array}{c}\text { A white crystalline solid } \\
\text { appeared, which settled well in } \\
\text { water. }\end{array}$ & $\begin{array}{c}\text { A white suspension was } \\
\text { formed, which did not } \\
\text { settle. }\end{array}$ \\
\hline
\end{tabular}

Table 2

Survey of mechanochemical synthesis $\mathrm{Al}(\mathrm{OH})_{3}$ from $2 \mathrm{KAl}\left(\mathrm{SO}_{4}\right)_{2} \cdot 12 \mathrm{H}_{2} \mathrm{O}$

\begin{tabular}{|c|c|c|}
\hline \multirow{2}{*}{ Reagent } & \multicolumn{2}{|c|}{$\mathbf{2 K A l}\left(\mathbf{S O}_{4}\right)_{2} \cdot \mathbf{1 2 H}_{2} \mathbf{O}$} \\
\cline { 2 - 3 } Observation & $\begin{array}{c}\text { Reaction did not survey during } \\
\text { mechanical grinding, when water was } \\
\text { added to mixture, intensive fizzing was } \\
\text { observed. }\end{array}$ & $\begin{array}{c}\text { Keaction did not survey during mechanical } \\
\text { grinding when water was added to mixture } \\
\text { fizzing was observed. }\end{array}$ \\
\hline Product & $\begin{array}{c}\text { A fine white suspension appeared, which } \\
\text { barely settled in water. }\end{array}$ & $\begin{array}{c}\text { A fine white suspension appeared, which } \\
\text { barely settled in water. }\end{array}$ \\
\hline
\end{tabular}

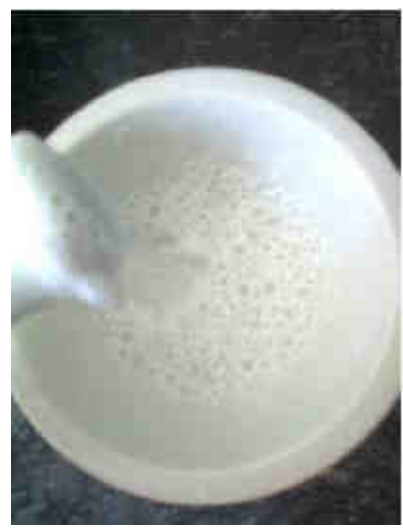

Fig. 1. Preparation of aluminium hydroxide in a mortar via the reaction scheme

Foaming and fizzing were caused by $\mathrm{CO}_{2}$ escaping from reaction mixture (Fig. 1). Changes during mechanical grinding were observed only in reactions (1) and (2). Only in 
the first case (reaction (1)) was the yield of aluminium hydroxide satisfactory. This resulted in the formation of a white gelatinous precipitate, which settled well in water. On standing for a few minutes, this precipitate became sufficiently dense for the water to be decanted with minimal loss of $\mathrm{Al}(\mathrm{OH})_{3}$.

\section{Worksheet for pupils}

\section{Experiment to prepare aluminium hydroxide}

Apparatus: mortar \& pestle, 2 beakers $\left(100 \mathrm{~cm}^{3}\right)$, measuring cylinder $\left(100 \mathrm{~cm}^{3}\right)$, filter funnel, filter paper, spatula, glass rod, white tile/glass, funnel holder \& stand, drying cabinet, 2 test tubes.

Reagents: aluminium chloride hexahydrate, sodium hydrogen carbonate, nitric acid $(5 \%)$, silver nitrate solution $(0.1 \mathrm{M})$.

Theory: Aluminium chloride and sodium hydrogen carbonate are both soluble in water. When these two solids are ground together, they react to form insoluble aluminium hydroxide, sodium chloride and water. The products can be separated by the techniques of solution, decantation and filtration.

Procedure:

1. Place $2 \mathrm{~g} \mathrm{NaHCO}_{3}$ and $1.9 \mathrm{~g} \mathrm{AlCl}_{3} \cdot 6 \mathrm{H}_{2} \mathrm{O}$ into a clean dry mortar.

2. Slowly add $30 \mathrm{~cm}^{3}$ distilled water, and grind the mixture gently until effervescence has ceased.

3. Pour the mixture into a beaker, stir with a glass rod, and allow the precipitatate of aluminium hydroxide to settle. While this is happening, set up the filter funnel and paper on the stand.

4. Once the precipitate has settled, carefully decant the solution (containing mainly sodium chloride), add $100 \mathrm{~cm}^{3}$ distilled water, stir the mixture again, and allow the precipitate to settle. Decant the solution again, and repeat the procedure with the distilled water a second time. The purpose of the repeated rinsing is to remove all traces of sodium chloride.

5. Add a third portion of distilled water to the aluminum hydroxide, stir thoroughly and immediately filter the suspension. Discard the filtrate. Open the filter paper containing the aluminium hydroxide residue, and place it on a white tile/glass plate. Allow to dry in the drying cabinet.

6. Place a small amount of dried product $(0.1 \mathrm{~g})$ into a test tube, add $2 \mathrm{~cm}^{3}$ of distilled water, stir and observe. Look carefully to see if any of the product dissolves.

7. Into another test place approx $0.5 \mathrm{~g}$ of dried product, followed by $2 \mathrm{~cm}^{3}$ of dilute nitric acid. Stir until the solid has dissolved (reacted). Add a few drops of silver nitrate solution. Are there any signs of a white precipitate?

\section{Observation:}

1. What do you observe during the stirring of the two different solids in the mortar?

2. What is the reason for your observations to question 1 ?

3. Explain why the suspension settles on addition of more water to the products of the reaction.

4. Describe the physical characteristics of the final product (colour, appearance, solubility in water).

5. Was there any sign of a precipitate when you added silver nitrate solution to the product of the reaction between your sample of aluminium hydroxide and nitric acid? 
What was the purpose of this test, and what does its result suggest about the purity of your product?

\section{Questions:}

1. Write down the equation for the chemical reaction in this experiment.

2. Write down the ionic equation, giving state symbols, for the reaction which you used to test for the presence of chloride ions.

3. Write down the names for the techniques which you used to purify your product.

\section{Conclusion:}

The products of the mechanochemical reaction between aluminium chloride hexahydrate and sodium hydrogencarbonate are:....

\section{Conclusions}

Mechanochemical syntheses have only rarely been undertaken in school laboratories. We have shown in this paper that such a technique is quite simple to do in practice, and that it has many benefits for students: it is relatively simple, safe, not too time-consuming and technically quite straightforward. At the same time, it enables pupils to develop their skills in manual dexterity. This technique is suitable for the preparation of several other inorganic substances. The experiment described in this paper was thoroughly tested by many 1 st grade high school pupils, and was developed and improved as a consequence of their experiences.

Mechanochemical reactions have many applications e.g. for organic synthesis, cocrystallisation, pharmaceutical and supramolecular processes, for the preparation of inorganic materials and metal complexes [10]. It is for these reasons that they constitute a most useful addition to the repertoire of the practical chemistry high school programme.

\section{Acknowledgements}

This work was supported by Ministry of Education of Slovak Republic (Grant Vega No. 1/0166/16).

\section{References}

[1] Munnings C, Badwal SPS, Fini D. Ionics. 2014;20:1117-1126. DOI: 10.1007/s11581-014-1079-2.

[2] Carlier L, Baron M, Chamayou A, Couarraze G. Powder Technol. 2013;240:41-47. DOI: 10.1016/j.powtec.2012.07.009.

[3] Hickenboth CR, Moore JS, White SR, Sottos NR, Baudry J, Wilson SR. Nature. 2007;446:423-427. DOI: 10.1038/nature05681.

[4] Carlier L, Baron M, Chamayou A, Couarraze G. Tetrahedron Let. 2011;52:4686-4689. DOI: 10.1016/j.tetlet.2011.07.003.

[5] Harris KDM. Nature Chem. 2013;5:12-14. DOI: 10.1038/nchem.1539.

[6] Garay AL, Pichon A, James SL. Chem Soc Rev. 2007;36:846-855. DOI: 10.1039/B600363J.

[7] James SL, Adams CJ, Bolm C, Braga D, Collier P, Friščić T et al. Chem Soc Rev. 2012;41:413-447. DOI: 10.1039/C1CS15171A.

[8] Billik P. Current Problems in Teaching Chemistry XVIII. Bratislava: Comenius University. 2014;24-32.

[9] Wixtrom A, Butler J, Abdel-Fattah T. J Chem Educ. 2014;91:1232-1235. DOI: 10.1021/ed4002267.

[10] Friščić T, Halasz I, Beldon PJ, Belenquer AM, Adams F, Kimber SAJ, et al. Nature Chem. 2013;5:66-73. DOI: $10.1038 /$ nchem.1505.

[11] Tan D, Loots L, Friščić T. Chem Commun. 2016;52:7760-7781. DOI: 10.1039/C6CC02015A.

[12] Klissurski D, Uzunova E. J Mater Chem. 1992;2:653-655. DOI: 10.1039/JM9920200653.

[13] Cheung EY, Kichin SJ, Harris KDM, Imai Y, Tajima N, Kuroda R. J Am Chem Soc. 2003;125:14658-14659. DOI: 10.1021/ja030506s. 
[14] Berry DE, Carrie P, Fawkes KL, Rebner B, Xing YS. J Chem Educ. 2010;87:533-534. DOI: 10.1021/ed800161a.

[15] Rojac T, Kosec M, Malič B, Holc J. Sci Sintering. 2005;37:61-67. DOI: 10.2298/SOS0501061R.

[16] Li Ch, Liang B. J Alloys Compounds. 2008;459:354-361. DOI: 10.1016/j.jallcom.2007.04.270.

[17] Užarevič K, Štrukil V, Mottillo C, Julien PA, Puškarić A, Friščić T, et al. Cryst Growth Des. 2016;16:2342-2347. DOI: 10.1021/acs.cgd.6b00137.

\title{
SYNTEZA MECHANOCHEMICZNA WODOROTLENKU GLINU W LABORATORIUM CHEMICZNYM W GIMNAZJUM/LICEUM
}

\begin{abstract}
Abstrakt: Mechanochemiczne reakcje polegają na szlifowaniu, frezowaniu, ugniataniu bez/lub ewentualnie z minimalnym udziałem rozpuszczalnika. Możliwe jest obserwowanie zmian m.in.: musowania, pienienia, zmiany koloru, powstania wody. Istnieje kilka prostych mechanochemicznych reakcji, które mogą być wykonane w laboratorium podczas lekcji w liceum. Dla uczniów szkół średnich istnieje pięć możliwości syntez nieorganicznych: syntezy mechanochemiczne, krystalizacja, strącanie, filtracja i dekantacja. W pracy przedstawiono proces wytwarzania wodorotlenku glinu $w$ warunkach szkolnych. Schematy pięciu mechanochemicznych reakcji zostały przetestowane, dodatkowo przedstawiono arkusz dla uczniów z zajęć laboratoryjnych oraz pytania związane z oczekiwanymi obserwacjami.
\end{abstract}

Słowa kluczowe: synteza mechanochemiczna, laboratoryjne umiejętności uczniów, wodorotlenek glinu 